\title{
Glutamate Metabolism in Plant Disease and Defense: Friend or Foe?
}

\author{
Hamed Soren Seifi, ${ }^{1}$ Jonas Van Bockhaven, ${ }^{1}$ Geert Angenon, ${ }^{2}$ and Monica Höfte ${ }^{1}$ \\ ${ }^{1}$ Laboratory of Phytopathology, Department of Crop Protection, Faculty of Bioscience Engineering, Ghent University, \\ Coupure Links 653, 9000 Ghent, Belgium; ' ${ }^{2}$ Laboratory of Plant Genetics, Institute for Molecular Biology and Biotechnology, \\ Vrije Universiteit Brussel, Pleinlaan 2, B-1050 Brussels
}

Submitted 14 July 2012. Accepted 13 January 2013.

\begin{abstract}
Plant glutamate metabolism (GM) plays a pivotal role in amino acid metabolism and orchestrates crucial metabolic functions, with key roles in plant defense against pathogens. These functions concern three major areas: nitrogen transportation via the glutamine synthetase and glutamine-oxoglutarate aminotransferase cycle, cellular redox regulation, and tricarboxylic acid cycle-dependent energy reprogramming. During interactions with pathogens, the host GM is markedly altered, leading to either a metabolic state, termed "endurance", in which cell viability is maintained, or to an opposite metabolic state, termed "evasion", in which the process of cell death is facilitated. It seems that endurance-natured modulations result in resistance to necrotrophic pathogens and susceptibility to biotrophs, whereas evasion-related reconfigurations lead to resistance to biotrophic pathogens but stimulate the infection by necrotrophs. Pathogens, however, have evolved strategies such as toxin secretion, hemibiotrophy, and selective amino acid utilization to exploit the plant GM to their own benefit. Collectively, alterations in the host GM in response to different pathogenic scenarios appear to function in two opposing ways, either backing the ongoing defense strategy to ultimately shape an efficient resistance response or being exploited by the pathogen to promote and facilitate infection.
\end{abstract}

The dynamic co-evolutionary conflict between phytopathogens and plants over the host nutritional resources has shaped distinct invasion strategies. Pathogens with a biotrophic lifestyle need living cells to ensure supplies for their growth and reproduction, while necrotrophs prefer dying tissues. Plants, on the other hand, have devised sophisticated mechanisms to deprive pathogens of nutrients. Upon timely perception of the presence of pathogenic microorganisms, a resistant plant is capable of deploying assorted types of defense strategies to halt pathogen progress. These strategies range from constructing physical barriers (e.g., reactive oxygen species [ROS]-dependent crosslinking of structural proteins in the cell wall) to de novo synthesis of various anti-microbial compounds (e.g., pathogenesisrelated proteins or phytoalexins). The regulation of genes controlling these well-established defense strategies has been exten-

Corresponding author: M. Höfte; Telephone: +32-9-264-60-17; Fax: +329-264-62-38; E-mail: monica.hofte@ugent.be

(C) 2013 The American Phytopathological Society sively studied through transcriptional profiling studies, particularly on incompatible plant-pathogen interactions. Commonly, these gene expression analyses also report marked alterations in transcriptional levels of genes encoding pathways related to primary metabolism, suggesting some roles for host central carbon/nitrogen $(\mathrm{C} / \mathrm{N})$ metabolism in relation with defense mechanisms.

There are dozens of research studies corroborating the link between primary metabolism and plant-pathogen interactions (Berger et al. 2007). The indispensable role of host primary metabolism in plant defense machinery has been recently reviewed (Bolton 2009). However, molecular knowledge on the role of central $\mathrm{C} / \mathrm{N}$ metabolism in plant defense mechanisms against different pathogenic behaviors is still scarce (Liu et al. 2010).

$\mathrm{N}$ is an essential element for plant growth and development. The assimilation of $\mathrm{N}$ onto $\mathrm{C}$ skeletons is the entry point for the newly uptaken $\mathrm{N}\left(\mathrm{NO}_{3}{ }^{-}\right.$and $\left.\mathrm{NH}_{4}{ }^{+}\right)$into the plant central metabolism (Lam et al. 1996). In higher plants, this physiologically crucial assimilation is carried out by the enzyme glutamine synthetase (GS), via the GS and glutamine-oxoglutarate aminotransferase (GOGAT) cycle (Cren and Hirel 1999; Forde and Lea 2007). Being at the interface of central $\mathrm{C}$ and $\mathrm{N}$ metabolism, the GS/GOGAT cycle constitutes a metabolic node with a pivotal position in plant amino acid metabolism by which the amino acid glutamate is continuously metabolized (Lam et al. 1996). Glutamate metabolism (GM) is known to play a central role in plant amino acid metabolism, orchestrating crucial metabolic functions, including assimilation or dissimilation of ammonia; amino acid transamination; and providing both the $\mathrm{C}$ skeleton and $\alpha$-amino group for biosynthesis of amino acids with key roles in plant defense such as $\gamma$-aminobutyric acid (GABA), arginine, and proline (Forde and Lea 2007; Galili et al. 2001). Thus, it seems that proper investigation of the interaction between plant central $\mathrm{C} / \mathrm{N}$ metabolism and defense mechanisms needs specific focus on the alterations in the host glutamate-mediated central metabolism during challenge with pathogens.

In this review, we categorize GM-related pathways that are altered in response to pathogen invasion in three major areas: i) $\mathrm{N}$ remobilization or reutilization, ii) host cell death or viability, and iii) tricarboxylic acid (TCA) cycle replenishment or exhaustion. We hypothesize that these alterations can ultimately result in two opposite metabolic states; namely, "endurance" and "evasion". We define endurance as a state in which cell viability is maintained via $\mathrm{N}$ reutilization through the GS/GOGAT cycle, ROS scavenging, or replenishment of the 
TCA cycle. In contrast, evasion is defined as a state that facilitates the process of cell death via $\mathrm{N}$ remobilization away from the GS/GOGAT cycle or ROS generation, or by exhausting the TCA cycle (Fig. 1). How these GM modulations in response to pathogens with different lifestyles will lead to resistance or susceptibility will be further discussed.

\section{N REMOBILIZATION OR REUTILIZATION}

Amino acids as nutritional sources for pathogens.

The premise that plant pathogens actively vie for a reliable $\mathrm{N}$ source in planta seems to be widely accepted (Bolton and Thomma 2008; Perez-Garcia et al. 2001; Pieterse et al. 1993; van den Ackerveken et al. 1994). It is also known that all $\mathrm{N}$ needed for fungal pathogen growth is derived from plant sources, including nitrate, ammonia, and amino acids (Solomon et al. 2003). In addition, for some fungal pathogens, utilization of amino acids seems to be generally preferred over inorganic $\mathrm{N}$ uptake (Walters and Bingham 2007). For instance, to supply the demand for organic $\mathrm{N}$, the biotrophic fungal pathogen Ustilago maydis has been reported to modulate the allocation flow of amino acids in its host, maize, to be mainly transported to the infection tumors (Horst et al. 2010). Likewise, in the compatible interaction between tomato and the biotrophic ascomycete Cladosporium fulvum, increased apoplastic levels of GABA in infected tissues have been suggested to be associated with the pathogen acquisition of an $\mathrm{N}$ source (Solomon and Oliver 2001, 2002). Some bacterial pathogens have also nutritionally evolved to utilize amino acids that are present in their hosts as both $\mathrm{C}$ and $\mathrm{N}$ sources. For example, whereas nonpathogenic strains of the genus Pseudomonas show potent nutritional versatility in the assimilation of various amino acids, the pathogenic Pseudomonas syringae pv. tomato has been demonstrated to be nutritionally specialized to catabolize the abundant amino acids in the tomato apoplast, such as GABA, aspartate, glutamate, and glutamine (Rico and Preston 2008).

\section{N transportation "away" \\ from the challenged cell (remobilization).}

The interdependency between the pathogen $\mathrm{C}$ and $\mathrm{N}$ needs and the plant central $\mathrm{C} / \mathrm{N}$ metabolism makes the basic substrate for a metabolic battle in which host GM plays a central role. In angiosperms, there are two distinct GS isoforms, cytosolic (GS1) and chloroplastic (GS2), which possess two different physiological roles in plant metabolism. GS1 is commonly believed to be involved in ammonium reassimilation during natural and stress-induced senescence, because the GSI transcript is known as a putative senescence-associated gene (SAG) marker. GS2, though, plays a crucial role in amino acid anabolism via assimilation of ammonium obtained from nitrate reduction and photorespiration (Bernard and Habash 2009; Perez-Garcia et al. 1998a and b). Early upregulation of several plant SAG markers, such as GS1 and asparagine synthetase (AS), in response to pathogenic infections has been repeatedly reported (AbuQamar et al. 2006; Pageau et al. 2006). Both asparagine and glutamine are key intermediates in $\mathrm{N}$ metabolism with a prominent role in $\mathrm{N}$ transport in higher plants (Lam et al. 1996). However, asparagine is known as a more efficient $\mathrm{N}$-transport compound due to its higher N/C ratio (2:4) compared with glutamine (2:5) (Kim et al. 1999). In some (hemi)biotrophic interactions, a rapid and strong invasion-triggered senescence is considered to be an effective defense strategy, termed a "slash-and-burn" defense strategy (Tavernier et al. 2007). This defense strategy consists of a timely and efficient remobilization of ammonium, in the form of asparagine or glutamine, away from the invaded area to the phloem. The rapid $\mathrm{N}$ export out of the challenged tissue may either protect the host $\mathrm{N}$ content or deprive the $\mathrm{N}$-starving pathogen of its nutri-

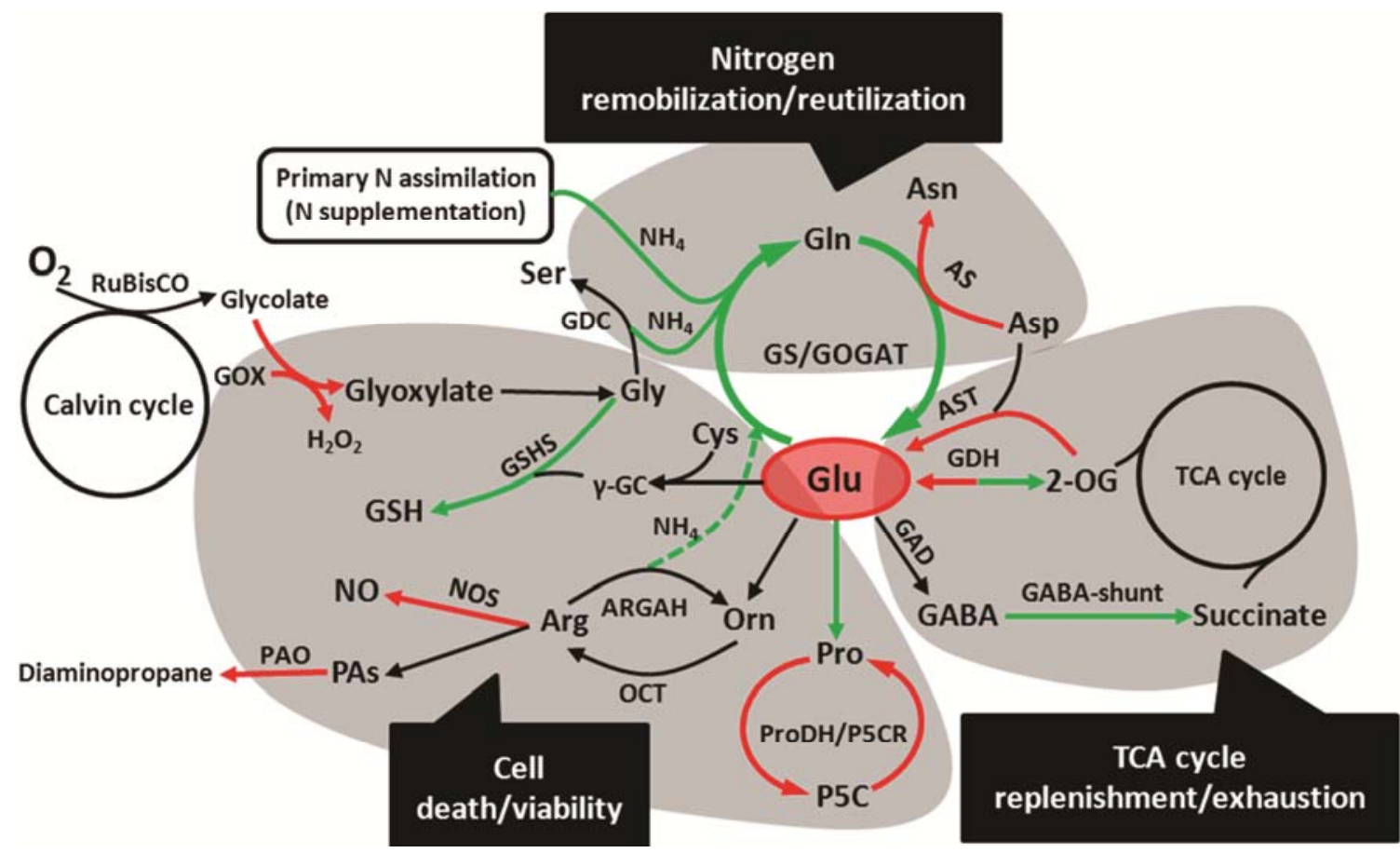

Fig. 1. Three major conflicts between the host glutamate metabolism (GM) and different pathogen virulence strategies. An integrated model of GM-dependent metabolic pathways, reported to be influential on plant defense responses. Green arrows indicate pathways associated with endurance and red arrows indicate pathways facilitating evasion. The central role of glutamate in supplying different defense-associated pathways can be seen in this model, as suggested previously (Brauc et al. 2011; Galili et al. 2001). ARGAH: arginase; AS: Asn synthetase; AST: Asp transaminase; GAD: Glu decarboxylase; $\gamma$-GC: gamma glutamylcysteine; GDC: glycine decarboxylase; GDH: Glu dehydrogenase; GOGAT: Gln-oxoglutarate aminotransferase; GOX: glycolate oxidase; GS: Gln synthetase; GSH: glutathione; GSHS: GSH synthetase; NOS: nitric oxide synthase; OCT: Orn carbamoyl-transferase; OG: oxoglutarate; PAO: polyamine oxidase; P5C: $\Delta^{1}$-pyrroline -5-carboxylate. 
tional target. Pageau and associates (2006) reported a marked and early ( $2 \mathrm{~h}$ postinoculation [hpi]) induction of GS1 during an incompatible interaction between tobacco and the hemibiotrophic $P$. syringae, which was independent of hypersensitive cell death (HR) induction. Accordingly, rapid accumulation of GSI mRNA, paralleled with the defense-related genes chalcone synthase and phenylalanine ammonia lyase $(P A L)$, were observed in an incompatible interaction between common bean and the hemibiotrophic pathogen Colletotrichum lindemuthianum (strain R255) (Tavernier et al. 2007). In tomato leaves infected by $P$. syringae, the expression of GS1 coupled with $A S 1$ was postulated to be responsible for forming a metabolic draining route, from the cytosol of challenged cells into the phloem. Through this route, the host transfers high levels of asparagine, carrying the free ammonia released by amino acid catabolism out of the invaded area (Olea et al. 2004). A rapid (5 hpi) and strong induction of $A S 1$ in pepper was shown to be essential for resistance against the hemibiotrophic bacterial pathogen Xanthomonas campestris pv. vesicatoria, whereas later (15 to $20 \mathrm{hpi}$ ) induction of the enzyme was associated with susceptibility (Hwang et al. 2011). These results highlight again the importance of timeliness in the slash-and-burn defense strategy. The same defensive phenomenon was also observed in transgenic Arabidopsis plants overexpressing pepper AS1 against $P$. syringae and the biotrophic oomycete Hyaloperonospora arabidopsidis (Hwang et al. 2011). Interestingly, $P$. syringae pv. tabaci seems to be able to neutralize this defensive $\mathrm{N}$-translocation via secretion of a dipeptide toxin, named tabtoxin, which irreversibly inhibits GS activity, resulting in an excess accumulation of free ammonia in the host tissue (Thomas et al. 1983; Turner 1981). In the same vein, drastic depletion of the GS2 isoform in infected leaves of tomato has been shown to be associated with the pathogenicity of $P$. syringae pv. tomato (Perez-Garcia et al. 1995).

\section{N transportation "toward" \\ the challenged cell (reutilization).}

The efficacy of the above-mentioned senescence-natured, slash-and-burn defense responses seems to be dependent on the pathogen's lifestyle. In fact, for some necrotrophic pathogens such as the ascomycete Botrytis cinerea, induction of senescence in the host tissue is known as a mode of pathogenicity (Swartzberg et al. 2008). Therefore, it could be hypothesized that an opposite defense strategy (i.e., translocation of $\mathrm{N}$ toward the invaded area in order to supply central metabolism of the challenged cells) could be effective for a resisting host. For instance, drastic depletion in glutamate storage in distal noninvaded regions of sunflower was postulated as a defensive reaction against $B$. cinerea. Through this mechanism, infected sunflower plants were presumed to provide $\mathrm{N}$ supply to be reutilized in the challenged area, eventually delaying the necrotroph-induced senescence (Dulermo et al. 2009). In the same vein, overexpression of glutamate receptors (transporters) increased ammonium transportation within the challenged cells in transgenic Arabidopsis plants, resulting in delayed senescence and increased levels of resistance against $B$. cinerea (Kang et al. 2006). This may also explain observed levels of resistance against $B$. cinerea in Arabidopsis lines overexpressing arginase, a urea-generating enzyme which eventually supplies the GS/GOGAT cycle with ammonium (Brauc et al. 2012). Interestingly, the necrotrophic pathogen Cochliobolus victoriae seems to be able to induce senescence in oat by interrupting the GS/GOGAT-mediated N-reutilization as an effective counter strategy. Secreting a host-selective toxin, victorin, the fungus targets glycine decarboxylase (GDC), the mitochondrial enzyme converting glycine to serine, which also feeds the photorespiration-derived ammonium into the
GS/GOGAT cycle (Navarre and Wolpert 1999). Through the inhibition of the GS/GOGAT-supplying GDC enzyme, the pathogen may neutralize this anti-senescence defense strategy in its host.

\section{HOST CELL DEATH OR VIABILITY}

The life span of a cell is controlled by many processes but one of the determining factors is the cellular redox balance (De Gara et al. 2003). In general, a more reductive balance lengthens the cell life span whereas oxidative stress leads to senescence and cell death. In plants, metabolic redox-dependent regulation of cell longevity plays a prominent role in shaping the overall response to different environmental stimuli, including biotic stresses (Foyer and Noctor 2005). On the other hand, pathogens can find ways to exploit these mechanisms in order to induce susceptibility in plants.

\section{Programmed cell death.}

Programmed cell death (PCD) is mainly controlled by perturbation in cellular redox balances through generation of different ROS such as hydrogen peroxide $\left(\mathrm{H}_{2} \mathrm{O}_{2}\right)$ (De Gara et al. 2003; Van Doorn et al. 2011). One of the best-studied types of PCD reactions in plant cells is the host $\mathrm{HR}$, a pervasive feature seen in incompatible plant-pathogen interactions (Dangl and Jones 2001). In this context, GM, embodying complex ROS generating or scavenging machinery, could also be considered a spatiotemporally important determinant of the host redox status during pathogen infection. It is noteworthy to underline that ROS-triggered HR may be particularly effective against pathogens with biotrophic (or often hemibiotrophic) lifestyles, due to the necessity of viable nutrition sources for these type of parasites. However, some necrotrophic pathogens may favor, or even induce, ROS-mediated cell death in their host tissue for a successful invasion (Govrin and Levine 2000; Van Baarlen et al. 2004).

\section{Photorespiratory ROS generation.}

Photorespiration is known as one of the main secondary sources of ammonium generation in the plant cell (Lea and Azevedo 2007), connecting the Calvin cycle to the GS/GOGAT cycle (Fig. 1). The key ROS-generating component of plant amino acid metabolism is the photorespiratory enzyme glycolate oxidase (GOX). The peroxisomal GOX enzyme also converts glycolate into glyoxylate, the main substrate for several key aminotransferases involved in amino acid metabolism (Fahnenstich et al. 2008).

Although the plasma membrane-bound NADPH oxidases are commonly known as the main sources of ROS production during HR, the ROS generated by intracellular organelles (mitochondria, chloroplasts, and peroxisomes) also have been shown to play an important role in initiating and shaping an HR reaction (Zurbriggen et al. 2010). The HR-dependent resistance in the melon genotype PI to the biotrophic oomycete pathogen Pseudoperonospora cubensis was shown to be controlled by three photorespiratory enzymes: GOX, serine glyoxylate aminotransferase (SGAT), and glutamate:glyoxylate aminotransferase (GGAT) (Kenigsbuch and Cohen 1992; Taler et al. 2004). It was revealed that the HR responsible for the arrest of the pathogen in the resistant genotype was linked to the higher expression of SGAT and GGAT genes, presumably via the overactivation of the ROS-generating enzyme (GOX) (Taler et al. 2004). GOX is also known to play a role in $\mathrm{H}_{2} \mathrm{O}_{2}$-fueled nonhost resistance in tobacco and Arabidopsis against nonhost strains of Pseudomonas syringae (Rojas et al. 2012). The latter work showed that alleviated $\mathrm{H}_{2} \mathrm{O}_{2}$ production in GOX-silenced plants is independent of the oxidative burst mediated by NADPH oxidase, suggest- 
ing GOX as an alternative source for ROS production during HR-dependent defense responses.

\section{Proline oxidation.}

An interesting illustration of metabolic regulation of plant cell redox homeostasis during pathogen infection is the proline pyrroline-5-carboxylate (Pro-P5C) cycle (Fig. 2). The Pro-P5C cycle comprises the cytosolic $\mathrm{P} 5 \mathrm{C}$ reductase (P5CR) and mitochondrial proline dehydrogenase (ProDH) (Cecchini et al. 2011; Natarajan and Becker 2012; Phang et al. 2008; Servet et al. 2012). In higher plants, proline is known to accumulate in response to different environmental stresses (Szabados and Savouré 2010). The main precursor of proline biosynthesis is glutamate, and P5CR catalyzes the last step of the biosynthetic pathway, whereas ProDH consumes the cytosolic pool of proline to produce P5C in the mitochondrion (Hare and Cress 1997). ProDH activity is known to be highly sensitive to many environmental stresses, therefore stimulating cytosolic proline accumulation in cells undergoing different type of stresses, including defense-associated oxidative stress (Verbruggen and Hermans 2008). On the other hand, it has been shown that, under certain circumstances, overactivation of ProDH results in an incomplete oxidation of proline which, in turn, transfers an overflow of electrons to the mitochondrial electron transfer chain, inducing mitochondrial redox imbalances (Miller et al. 2009). In a recent study in Arabidopsis, ProDH was suggested to function as a defense gene, contributing to timely HR induction against $P$. syringae (Cecchini et al. 2011). Therein, ProDHsilenced plants were also shown to be compromised in a rapid HR development, displaying reduced cell death levels and enhanced susceptibility to an avirulent strain of the bacterial pathogen. A similar role was reported for $\mathrm{ProDH}$ and the other main P5C-generating enzyme, ornithine $\delta$-aminotransferase, in the induction of the HR-mediated nonhost resistance in Arabidopsis and Nicotiana benthamiana against different strains of P. syringae (Senthil-Kumar and Mysore 2012).

\section{Arginine-dependent nitric oxide generation.}

In synergy to ROS, reactive $\mathrm{N}$ species such as nitric oxide (NO) also act as important signaling molecules in the plant immune system, orchestrating different defense responses ranging from transcriptional and hormonal regulations to HR development (Moreau et al. 2010; Mur et al. 2006). Despite the large body of evidence supporting the importance of nitrate and

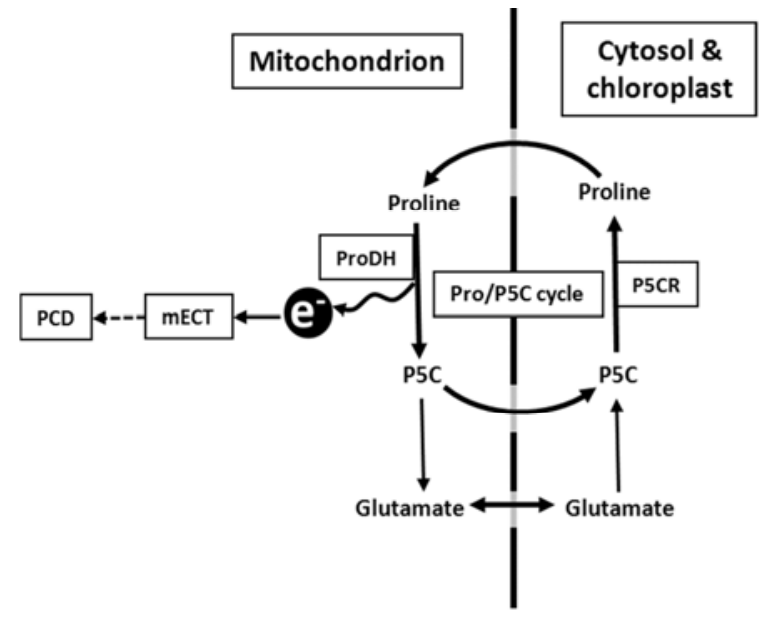

Fig. 2. Proline/pyrroline-5-carboxylate (P5C) cycle. Overactivation of proline dehydrogenase (ProDH) results in an incomplete oxidation of proline and transfers an overflow of electrons to the mitochondrial electron transfer chain (mETC), inducing programmed cell death (PCD) (Miller et al. 2009). nitrite in NO biosynthesis, existence of an arginine-dependent NO biosynthetic route also has been reported in many plants (Moreau et al. 2010). The NADPH-dependent enzyme nitric oxide synthase catalyzes the two-step oxidation of L-arginine to NO and citrulline (Crawford 2006). Interestingly, preharvest L-arginine treatment on tomato fruit has been shown to be sufficient to induce postharvest resistance against $B$. cinerea through its effect on increased NO biosynthesis and, consequently, overactivation of defensive enzymes such as PAL, chitinase, and glucanase (Zheng et al. 2011).

\section{Polyamine oxidation.}

Arginine is also known as the main precursor for polyamine (PA) biosynthesis. In higher plants, arginine decarboxylase (indirectly) and ornithine decarboxylase (directly) form putrescine, the main precursor of other PA (Kuznetsov et al. 2006). PA not only play a signaling role in plant defense but their oxidation also imposes oxidative stress leading to cell death after infection (Walters 2003). During the incompatible interaction between barley and the powdery mildew fungus Blumeria graminis $\mathrm{f}$. sp. hordei, increased levels of PA and PA-oxidase were shown to be associated with cell death (Cowley and Walters 2002). This might explain why interference in arginine biosynthesis is a foremost invasion strategy for some pathogens. For instance, the non-host specific antimetabolite toxins, phaseolotoxin and mangotoxin, produced by virulent strains of $P$. syringae have been shown to inhibit different steps in the arginine biosynthetic pathway, facilitating bacterial colonization (Arrebola et al. 2003; Tourte and Manceau 1995). Similar mechanisms can be considered for a report on $P$. syringae pv. phaseolicola and vetch interaction, where downregulation in arginine biosynthesis was associated with the inhibitory effect of phaseolotoxin resulting in susceptibility (Patil et al. 1972). Likewise, an uncharacterized toxic activity of some strains of $P$. syringae pv. tomato seems to have a similar mode of action (Arrebola et al. 2003).

Because there is an indirect connection between GM and HR-mediated defense responses via NO biosynthesis and PA oxidation, further focus on defense-associated NO or PA alterations is outside of the intended scope of this review paper.

\section{Host cell viability.}

The redox-regulating capacities of GM also lie in the ability to scavenge oxidative stress. The ROS-scavenging function of some GS/GOGAT-dependent metabolic pathways creates a reducing environment that guards host cell viability. Here, quite contrary to PCD, an increase in cell longevity is presumed to be an effective defense strategy against necrotrophic pathogens that benefit from an early cell death, while it can potentially promote biotrophic interactions.

\section{Redox regulatory role of the GS/GOGAT cycle.}

A redox-balancing role was suggested for the functionality of the GS/GOGAT cycle, negatively modulating HR-mediated defense responses (Liu et al. 2010). The authors demonstrated that, in Arabidopsis leaf cells, inhibition of the GS/GOGATsupplying glutamine transportation from the apoplast into the cytosol leads to resistance against the hemibiotrophic anthracnose fungus Colletotrichum higgisianum and the biotrophic powdery mildew pathogen Erysiphe cichoracearum. Accordingly, loss of function of the Arabidopsis isocitrate dehydrogenase enzyme, generating 2-oxoglutarate as the main $\mathrm{C}$ skeleton required for normal functionality of the GS/GOGAT cycle, was shown to induce redox perturbations and cell death. Consequently, this confers resistance against the virulent DC3000 strain of P. syringae pv. tomato (Mhamdi et al. 2010). However, continuation of GS/GOGAT cycle operation, through the 
overactivation of the cytosolic GS1, was a feature seen in early stages of a compatible interaction between $P$. syringae and tomato (Perez-Garcia et al. 1998a and b). Collectively, it seems that GS/GOGAT cycle functionality could be considered to be a molecular on/off switch of cell viability, negatively controlling the overall resistance response against biotrophic-natured virulence strategies (including hemibiotrophic interactions). By contrast, it could be expected that the impact of this master switch on necrotrophic invasions might work in the opposite way. Interestingly, it has been recently observed in our lab that the resistance seen in sitiens, an abscisic acid-deficient tomato mutant, against Botrytis cinerea (Asselbergh et al. 2007; Curvers et al. 2010) correlates with the ability of the mutant to retard the necrotrophic pathogen-induced cell death by maintaining the GS/GOGAT cycle activity (H. S. Seifi and M. Höfte, unpublished data).

\section{Glutathione-mediated ROS scavenging.}

Being involved in the biosynthesis of a highly important antioxidant metabolite, the tripeptide $\gamma$-glutamylcysteinylglycine or glutathione (GSH), GM may modulate redox alterations occurring during pathogenic infections. GSH is known to play several roles in plant physiology and development (Noctor et al. 2012), as well as in plant defense responses (De Gara et al. 2003). Increased levels of GSH accumulation in tobacco and barley have been shown to occur during HR-mediated defense responses against biotrophic pathogens, as a protective mechanism in the cells surrounding the HR-undergoing areas, mitigating further oxidative damage to the rest of the tissue (ElZahaby et al. 1995; Fodor et al. 1997). Likewise, peroxisomal accumulation of GSH was shown to be part of an antioxidative defense reaction to counteract $P$. syringae-induced cell death in Arabidopsis (Grosskinsky et al. 2012). On the other hand, GSH content could also be exploited by some pathogens to establish their infectious colonization. For instance, lower levels of GSH have been observed in tomato leaves infected with the ROS-favoring pathogen $B$. cinerea (Kuzniak and Sklodowska 1999) as well as in Avena sativa leaves during the necrotrophic interaction with Drechslera spp. (Vongonner and Schlösser 1993). According to the latter reports, attenuating the antioxidant capacity of the host tissue is crucial for a successful necrotrophic virulence strategy.

\section{Proline accumulation.}

Proline accumulation was particularly observed in leaf areas surrounding HR lesions in a gene-for-gene mediated incompatible interaction between Arabidopsis Co1-0 plants and $P$. syringae (Fabro et al. 2004). The authors then hypothesized that proline might play a protective role, as a free radical scavenger, to ameliorate the burden of oxidative damage to the photosynthetic tissues around the challenged area.

Taken all together, it seems that plant GM plays a dual role as both an inducer and a scavenger of oxidative stress in the challenged site, leading to either PCD or increased cell viability. This redox-regulating potential, on the one hand, is important in the defense against pathogens with different lifestyles whereas, on the other hand, pathogens may also exploit these very mechanisms to induce susceptibility.

\section{TCA CYCLE REPLENISHMENT OR EXHAUSTION}

\section{TCA cycle replenishment.}

All levels of inducible resistance reactions are known as highly energy-demanding processes in plants (Berger et al. 2007; Heil and Bostock 2002), heavily draining TCA cyclegenerated energy and intermediates (Bolton 2009; Kinnersley and Turano 2000). The TCA cycle plays a crucial anabolic role in supporting the costly defense-related metabolic pathways, such as stress-induced phenylpropanoid metabolism, which are known to consume up to $20 \%$ of the total photosynthetic $\mathrm{C}$ in the plant (Dennis and Blakeley 1995). This huge demand highlights the significance of anaplerotic reactions (i.e., "filling-up reactions") (Kornberg 1965), such as the GABA shunt, to replenish the cycle and ensure its constant functionality during such circumstances.

The GABA shunt is a cytosolic-mitochondrial pathway that connects the GS/GOGAT cycle to the TCA cycle consisting of three key enzymes: glutamate decarboxylase (GAD), GABA transaminase (GABA-T), and succinic-semialdehyde dehydrogenase (SSADH) (Fait et al. 2008). Specifically using glutamate as the main precursor for GABA biosynthesis, GAD activity catalyzes the first step of the GABA shunt in the cytosol, while the other two steps of the shunt, GABA-T and SSADH, have been shown to locate in mitochondria (Shelp et al. 2012). Therefore, it could be postulated that the TCA-replenishing role of the GABA shunt during stresses requires maintaining a constant level of cytosolic glutamate generation through the GS/GOGAT cycle, again highlighting the central role of GM in orchestrating several defense-related pathways in host amino acid metabolism.

The physiological link between the GABA shunt and primary $\mathrm{C}$ metabolism via the TCA cycle has recently attracted some attention (Arujo et al. 2008; Fait et al. 2008; StudartGuimaraes et al. 2007). The latter authors have demonstrated that, in potato, inhibition of 2-oxoglutarate dehydrogenase (the second enzyme of the TCA cycle bypassed by the GABA shunt) induces a clear upregulation in the GABA-shunt-comprising genes. Likewise, GABA transportation into the mitochondria under $\mathrm{C}$ limitation was shown to be essential for proper C metabolism in Arabidopsis (Michaeli et al. 2011).

Although there are a number of studies suggesting roles for GABA shunt in response to abiotic stresses (Bouché et al. 2003; Kinnersley and Turano 2000; Ludewig et al. 2008), information on the molecular mechanism underpinning metabolic roles of GABA shunt in plant defense mechanism against pathogens is still scarce. A TCA-replenishing role for the GABA shunt was proposed when a novel $G A B A-T$ gene was found to be induced in rice leaves during challenge with different abiotic and biotic stresses, including ultraviolet radiation, mechanical wounding, and infection with the hemibiotrophic blast fungus Magnaporthe oryzae (Wu et al. 2006). Accordingly, the race-nonspecific Lr34-mediated resistance response against the wheat leaf rust pathogen Puccinia triticina has been shown to be considerably energy intensive, entailing concurrent upregulation of the TCA cycle and the GABA shunt (Bolton et al. 2008). It was also shown that overexpression of cytosolic aspartate transaminase in Arabidopsis increases susceptibility to $B$. cinerea, presumably through overconsumption of the cytosolic glutamate pool, resulting in depletion of some important defensive metabolites such as GABA (Brauc et al. 2011).

\section{TCA cycle exhaustion.}

The senescence-associated gene glutamate dehydrogenase $(\mathrm{GDH})$ is another linking route between the TCA and the GS/GOGAT cycles, where the aminating activity of GDH adds an amino group to the TCA-intermediate metabolite 2-oxoglutarate, to generate glutamate (Masclaux-Daubresse et al. 2002). This TCA-draining function of the enzyme has been reported to occur in response to bacterial as well as viral invasions (Pageau et al. 2006). The latter authors have observed GDH enzymatic overactivation in tobacco leaves during infections with Pseudomonas syringae and Potato virus $Y$, presumably facilitating the cell death process in the host tissue. Likewise, 
recent transcriptional analysis suggests that draining of the TCA cycle due to an increased expression of GDH might facilitate the progression of the necrotrophic fungus Cochliobolus miyabeanus in susceptible rice plants, while the opposite was observed in more resistant plants. The GDH-mediated export of glutamate from the mitochondria and subsequent draining of the TCA cycle might be a strategy of the fungus to induce senescence and susceptibility (J. Van Bockhaven and M. Höfte, unpublished data). A similar hypothesis can explain why overexpression of aspartate transaminase, which reversibly converts 2-oxoglutarate into glutamate, increases susceptibility to $B$. cinerea in Arabidopsis (Brauc et al. 2011). Likewise, the necrotrophic fungus Alternaria citri, via secretion of the ACR-toxin, induces leakage of $\mathrm{NAD}^{+}$from the TCA cycle, causing cell death in rough lemon (Tsuge et al. 2013). Collectively, it seems that exhausting the host crucial anabolic apparatus, the TCA cycle, can be considered an effective virulence strategy for some necrotrophic pathogens.

\section{To endure or to evade, that is the question.}

The modulation of disease resistance via alterations in host GM seems to be a complex phenomenon. All of the previously discussed reconfigurations of the GM of different host plants in response to biotrophic, necrotrophic, and hemibiotrophic pathogens are summarized in Table 1, clearly showing that the ultimate outcome of the overall defense response is largely dependent on the lifestyle of the invading pathogen. For instance, whereas evasion-related strategies such as the overactivation of the cell-death-facilitating aminating activity of GDH in the challenged tissue could be effective in shaping a successful HR-dependent defense mechanism against a biotrophic pathogen (Pageau et al. 2006), the same reaction would be greatly favorable for a necrotroph (Dulermo et al. 2009). This dual pathogenesis-dependent role of GM might also explain the observed contradicting effect of $\mathrm{N}$ supply in tomato against different pathogens (Hoffland et al. 2000). According to this study,

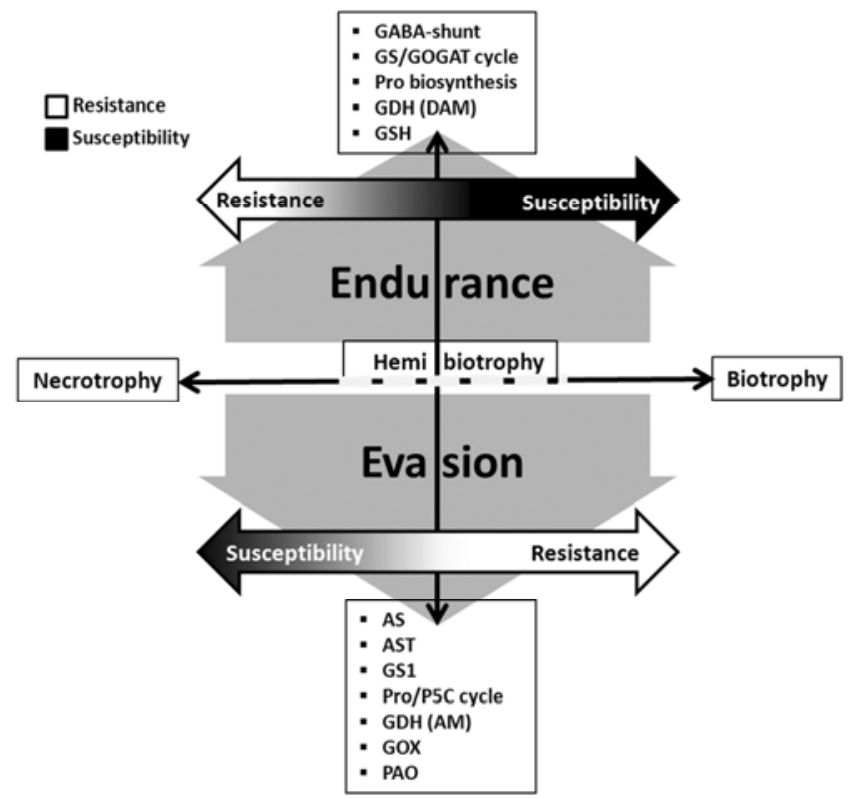

Fig. 3. Pathogen virulence strategy versus host glutamate metabolism (GM). A hypothetical model showing how plant GM, in response to pathogens with different virulence strategies, may modulate the outcome of defense response. AS: Asn synthetase; AST: Asp transaminase; GDH (AM/ DAM): Glu dehydrogenase (aminating/deaminating); GOGAT: Gln-oxoglutarate aminotransferase; GOX: glycolate oxidase; GS: Gln synthetase; GSH: glutathione; PAO: polyamine oxidation (PA-oxidase); P5C: pyrroline5-carboxylate. increased $\mathrm{N}$ concentrations in tomato hydroponic cultivation could reduce susceptibility against $B$. cinerea, whereas it significantly increased susceptibility against the biotrophic powdery mildew fungus Oidium lycopersicum. Similarly, Lecompte and associates (2010) demonstrated that a high $\mathrm{N}$ nutrition lowers the susceptibility of tomato to $B$. cinerea stem infections. It could be hypothesized that $\mathrm{N}$ nutrition replenishes the GS/ GOGAT cycle, boosting the endurance state in infected tissues. This enables the plant to retard the necrotrophic pathogeninduced cell death, leading to increased resistance. However, during the true biotrophic interaction with O. lycopersicum, the $\mathrm{N}$-induced endurance state sustains the host cell viability, which is extremely beneficial for the pathogen.

Taken all together, a simplified juxtaposition model is proposed, describing how the two main functionalities of host GM (i.e. evasion and endurance) in response to different infection scenarios (i.e., biotrophic, hemibiotrophic, and necrotrophic) can modulate the overall defense reaction (Fig. 3). It seems that reconfiguration of the host GM during pathogenic challenge functions as a "double-edged sword", either backing the ongoing defensive strategy or being exploited by the pathogen, thus facilitating infection. According to this model, the state of "resistance" depends on the concurrence of certain metabolic events in the host that oppose the metabolic demands of the pathogen. Yet, how mechanistically a resistant plant tailors and fine tunes these metabolic rearrangements according to the lifestyle of the invading pathogen merits further elucidation.

\section{Pathogen exploitation of the host GM.}

Although the main scope of the current review was to focus on the role of host GM reconfigurations in plant-pathogen interactions, it is also important to understand how pathogens may exploit plant GM to their own benefit.

Secretion of various effectors or toxins is broadly known as a potent virulence mechanism that enables pathogens to subvert host cell metabolic functions (Block et al. 2008; Duke and Dayan 2011). For instance, $P$. syringae, via secreting a constellation of type III effectors (TTE) or various toxins into the target cell, is able to manipulate the host central metabolism, including amino acid metabolism, to its own benefit (Rico et al. 2011). Despite the currently scarce information on TTE that specifically target host central $\mathrm{C} / \mathrm{N}$ metabolism, there are some available data about pathogen-derived toxins with this particular mode of action, termed "antimetabolite" toxins (Arrebola et al. 2011). Some of the most notable examples of these toxins were briefly illustrated in this review in their relevant contexts and are summarized in Table 2. However, in addition to these toxinmediated virulence mechanisms, pathogens may deploy other strategies to cope with defense-associated host GM reconfigurations. Here, we provide only a preliminary insight into this fertile area, which definitely warrants further exploration.

\section{Timely switching of pathogenicity modes.}

Some pathogens, mostly hemibiotrophs, are able to neutralize plant GM-mediated defenses by responsively adapting their lifestyle to these metabolic reconfigurations. An interesting example of this has been depicted in a study by Tavernier and associates (2007) on the interaction between Colletotrichum lindemuthianum and Phaseolus vulgaris. In this compatible pathosystem, upon the pathogen ingress, a rather late GS1-mediated evasion of the first biotrophic challenge occurs in the host, resulting in glutamine accumulation in the phloem around the infection site. Concomitantly, $C$. lindemuthianum shifts into a necrotrophic invasion style, presumably because the increased vascular glutamine concentration is perceived as a signal of the host escape. This timely transition in virulence strategy enables the anthracnose pathogen to trap high levels 
Table 1. Roles of host glutamate metabolism in plant-pathogen interactions ${ }^{\mathrm{a}}$

\begin{tabular}{|c|c|c|c|c|c|}
\hline Interactions, host & Pathogen & GDMP involved & GDMP mode of action & Effect $^{\text {b }}$ & Reference \\
\hline \multicolumn{6}{|l|}{ Biotrophic } \\
\hline Barley & $\begin{array}{l}\text { Erysiphe graminis } \\
\text { f. sp. hordei }\end{array}$ & $\uparrow$ GSHS & $\begin{array}{l}\text { Cell viability: Restricting the extent of HR, protecting } \\
\text { noninvaded areas }\end{array}$ & + & El-Zahaby et al. 1995 \\
\hline Tobacco & Tobacco mosaic virus & $\uparrow$ GSHS & $\begin{array}{l}\text { Cell viability: Restricting the extent of HR, protecting } \\
\text { noninvaded areas }\end{array}$ & + & Fodor et al. 1997 \\
\hline Melon & $\begin{array}{l}\text { Pseudoperonospora } \\
\text { cubensis }\end{array}$ & 个SGT, AGT, GOX & Cell death: Generation of ROS, HR-mediated defense & + & Taler et al. 2004 \\
\hline Wheat & Puccinia triticina & $\uparrow$ GABA shunt & $\begin{array}{l}\text { TCA replenishment: Replenishing the TCA cycle, } \\
\text { providing energy for the Lr34-mediated resistance }\end{array}$ & + & Bolton et al. 2008 \\
\hline Tomato & Cladosporium fulvum & $\uparrow$ GABA biosynthesis & $\begin{array}{l}\text { Apoplastic GABA accumulation, providing } \mathrm{N} \text { source } \\
\text { for the pathogen }\end{array}$ & _- & $\begin{array}{l}\text { Solomon and Oliver } \\
2002\end{array}$ \\
\hline Arabidopsis & Erysiphe cichoracearum & $\begin{array}{l}\downarrow \text { GS/GOGAT (via the Gln } \\
\text { transporter, LHT1) }\end{array}$ & $\begin{array}{l}\text { Cell death: Induction of redox imbalance, resulting } \\
\text { in a HR-mediated defense }\end{array}$ & + & Liu et al. 2010 \\
\hline Arabidopsis & $\begin{array}{l}\text { Hyaloperonospora } \\
\text { arabidopsidis }\end{array}$ & $\uparrow$ AS & $\mathrm{N}$ remobilization: Facilitating cell death & + & Hwang et al. 2011 \\
\hline \multicolumn{6}{|l|}{ Necrotrophic } \\
\hline Arabidopsis & Botrytis cinerea & $\uparrow$ Glu transporters & $\begin{array}{l}\mathrm{N} \text { reutilization: Increase in } \mathrm{NH}_{4} \text { reutilization, } \\
\text { delaying senescence }\end{array}$ & + & Kang et al. 2006 \\
\hline Arabidopsis & B. cinerea & $\uparrow A R G A H$ & $\begin{array}{l}\mathrm{N} \text { reutilization: Increase in } \mathrm{NH}_{4} \text { reutilization, } \\
\text { delaying senescence }\end{array}$ & + & Brauc et al. 2011 \\
\hline Tomato & B. cinerea & $\begin{array}{l}\uparrow \text { Arg-dependent NO } \\
\text { biosynthesis }\end{array}$ & NO-induced PR protein accumulation & + & Zheng et al. 2011 \\
\hline Tomato & B. cinerea & ND & $\begin{array}{l}\mathrm{N} \text { reutilization: Induction of resistance in } \mathrm{N} \\
\text { supplemented plants }\end{array}$ & + & Lecompte et al. 2010 \\
\hline Arabidopsis & B. cinerea & $\uparrow \mathrm{AST}$ & $\begin{array}{l}\text { TCA exhaustion: Over-consumption of cytosolic } \\
\text { Glu pool, resulting in depletion of GABA }\end{array}$ & - & Brauc et al. 2011 \\
\hline Oat & Drechslera spp. & $\downarrow$ GSHS & Cell death: Facilitating cell death & - & $\begin{array}{l}\text { Gonnen and Schlöser, } \\
1993\end{array}$ \\
\hline Oat & Cochliobolus victoriae & $\downarrow_{\text {GDC }}$ & Inhibiting $\mathrm{N}$ reutilization & - & $\begin{array}{l}\text { Navarre and Wolpert, } \\
1999\end{array}$ \\
\hline Sunflower & B. cinerea & $\uparrow \mathrm{GDH}$ & TCA exhaustion: Facilitating cell death & _ & Dulermo et al. 2009 \\
\hline Tomato & B. cinerea & $\downarrow$ GSHS & Cell death: Facilitating cell death & - & $\begin{array}{l}\text { Kuzniak and } \\
\text { Sklodowska } 1999\end{array}$ \\
\hline \multicolumn{6}{|l|}{ Hemibiotrophic } \\
\hline Arabidopsis & $\begin{array}{r}\text { Colletotrichum } \\
\text { higginsianum }\end{array}$ & $\begin{array}{l}\downarrow \text { GS/GOGAT (via the Gln } \\
\text { transporter, LHT1) }\end{array}$ & $\begin{array}{l}\text { Cell death: Induction of redox imbalance, resulting } \\
\text { in a HR-mediated defense }\end{array}$ & + & Liu et al. 2010 \\
\hline Arabidopsis & $\begin{array}{l}\text { Pseudomonas syringae } \mathrm{pv} . \\
\text { tomato }\end{array}$ & $\uparrow \mathrm{AS}$ & $\mathrm{N}$ remobilization: Facilitating cell death & + & Hwang et al. 2011 \\
\hline Arabidopsis & P. syringae pv. tomato & 个P5CS (Pro biosynthesis) & $\begin{array}{l}\text { Cell viability: Restriction of the extent of HR, } \\
\text { protecting noninvaded areas }\end{array}$ & + & Fabro et al. 2004 \\
\hline Arabidopsis & P. syringae pv. tomato & $\uparrow$ ProDH/P5CR & $\begin{array}{l}\text { Cell death: Induction of electron overflow in mETC, } \\
\text { resulting in a HR-mediated defense }\end{array}$ & + & Cecchini et al. 2011 \\
\hline Arabidopsis & $\begin{array}{l}\text { P. syringae pvs. syringae } \\
\text { and tabaci }\end{array}$ & $\uparrow$ GOX & $\begin{array}{l}\text { Cell death: Induction of ROS-dependent nonhost } \\
\text { resistance }\end{array}$ & + & Rojas et al. 2012 \\
\hline Common bean & $\begin{array}{l}\text { Colletotrichum } \\
\text { lindemuthianum }\end{array}$ & $\uparrow$ GS1-GDH & $\begin{array}{l}\text { N remobilization: Depriving the pathogen } \\
\text { of nutrients (slash and burn defense strategy) }\end{array}$ & + & Tavernier et al. 2007 \\
\hline Tobacco & $\begin{array}{l}\text { P. syringae pvs. } \\
\text { tabaci } \text { and tomato }\end{array}$ & $\uparrow \mathrm{GS} 1, \mathrm{GDH}$ & $\mathrm{N}$ remobilization: Facilitating cell death & + & Pageau et al. 2006 \\
\hline Tobacco & P. syringae pv. tomato & $\uparrow G O X$ & $\begin{array}{l}\text { Cell death: Induction of ROS-dependent nonhost } \\
\text { resistance }\end{array}$ & + & Rojas et al. 2012 \\
\hline Tomato & P. syringae pv. tomato & $\uparrow G S 1-A S$ & $\begin{array}{l}\mathrm{N} \text { remobilization: Transfer of free ammonia out } \\
\text { of the invaded area }\end{array}$ & + & Olea et al. 2004 \\
\hline Tomato & P. syringae pv. tomato & $\begin{array}{l}\downarrow_{\mathrm{GS} / \mathrm{GOGAT}} \\
\quad \text { (via ICDH enzyme) }\end{array}$ & $\begin{array}{l}\text { Cell death: Induction of redox imbalance, resulting } \\
\text { in a HR-mediated defense }\end{array}$ & + & Mhamdi et al. 2010 \\
\hline Rice & Magnaporthe oryzae & $\uparrow$ GABA-T & $\begin{array}{l}\text { TCA replenishment: Restricting the levels of host } \\
\text { cell death }\end{array}$ & + & Wu et al. 2006 \\
\hline Pepper & $\begin{array}{l}\text { Xanthomonas campestris } \\
\text { pv. vesicatoria }\end{array}$ & $\uparrow \mathrm{AS}$ & $\mathrm{N}$ remobilization: Facilitating cell death & + & Hwang et al. 2011 \\
\hline Arabidopsis & P. syringae pv. tomato & $\uparrow$ AtGAT1 (GABA transporter) & $\begin{array}{l}\text { Apoplastic GABA accumulation, providing } \mathrm{N} \text { source } \\
\text { for the pathogen }\end{array}$ & - & Ward et al. 2010 \\
\hline Mango & P. syringae pv. syringae & $\downarrow$ Arg biosynthesis & ND & - & Arrebola et al. 2003 \\
\hline Tobacco & P. syringae pv. tabaci & $\begin{array}{l}\downarrow \text { GS/GOGAT (via irreversible } \\
\text { inhibition of GS) }\end{array}$ & $\begin{array}{l}\text { Inhibition of } N \text { remobilization: Induction of the } \\
\text { accumulation of free ammonia }\end{array}$ & _- & Turner 1981 \\
\hline Vetch & $\begin{array}{l}\text { P. syringae } \mathrm{pv} . \\
\text { phaseolicola }\end{array}$ & $\downarrow$ Arg biosynthesis & ND & _ & Patil et al. 1972 \\
\hline
\end{tabular}

a TCA: tricarboxylic acid; GDMP: glutamate-dependent metabolic pathway; ND: not determined; $\uparrow:$ upregulation; $\downarrow$ : downregulation; HR: hypersensitive cell death. Enzyme abbreviations: AS: Asn synthetase; AGT: Ala glyoxylate aminotransferase; ARGAH: arginase; AST Asp transaminase; GABA-T: GABA transaminase; GAD: Glu decarboxylase; GDC: glycine decarboxylase; GDH: Glu dehydrogenase; GOGAT: Gln-oxoglutarate aminotransferase; GOX: glycolate oxidase; GS: Gln synthetase; GSH: glutathione; GSHS: GSH synthetase; NOS: nitric oxide synthase; OCT: Orn carbamoyl-transferase; P5CR: $\Delta^{1}$-pyrroline -5-carboxylate reductase; P5CS: $\Delta^{1}$-pyrroline -5-carboxylate synthase; PAO: polyamine oxidase; ProDH: Pro dehydrogenase; SGT: Ser glyoxylate aminotransferase.

${ }^{\mathrm{b}}$ Effect on overall resistance response. 
of glutamine in the phloem, before the host can efficiently translocate its $\mathrm{N}$ reservoir out of the challenged area. In spite of the competence of this adaptable infection strategy, an early and strong evasion-based defense reaction in the host has been shown to be sufficient to stop the development of some potent hemibiotrophic pathogens such as C. higgisianum (Liu et al. 2010), and Phytophthora infestans (Shibata et al. 2010) while they are still in their biotrophic phase.

\section{Selective amino-acid utilization.}

Deciphering why some pathogens metabolize or neglect particular amino acids during the infection course may provide an intriguing insight into the metabolic interface between plants and pathogens.

It has been shown that $P$. syringae pv. tomato is well-adapted to metabolize the six most abundant amino acids in the tomato apoplast as both $\mathrm{N}$ and $\mathrm{C}$ sources. Most low-abundant amino acids are used very poorly or not at all, except for asparagine, arginine, proline, and histidine (Rico and Preston 2008). Utilization of histidine has been attributed to the energy-intensive anabolism of the amino acid by the pathogen itself; however, it is not clear why the three other amino acids are utilized. Nutritional value is probably not the only evolutionary cause that has made these particular amino acids so important, because the highly abundant N-rich amino acids such as aspartate, glutamate, and glutamine should be sufficient to supply the $\mathrm{N}$ need of the pathogen. By selective utilization of asparagine, Pseudomonas syringae may affect $A S$ expression in its host. However, as previously discussed, early and strong induction of $A S$ in the host seems to be linked with a slash-and-burn-natured defense strategy (Hwang et al. 2011). Therefore, a late induction of AS, as observed in the compatible interaction of $P$. syringae-tomato at 2 dpi peaking at $4 \mathrm{dpi}$ (Olea et al. 2004), might be beneficial for the hemibiotrophic pathogen, facilitating the cell death associated with the necrotrophic phase of the infection. Confirmingly, no significant alterations were observed in asparagine levels of Arabidopsis leaves during early stages (8 and $12 \mathrm{hpi}$ ) of $P$. syringae infection (Ward et al. 2010).

Likewise, regarding the roles of arginine and proline in the host GM-mediated defenses (Fig. 1), it can be hypothesized that the ability to utilize these amino acids might help the pathogen to seize two important defense-related precursors, repressing the following HR-inducing modules.

Another example of a utilization-dependent virulence strategy can be seen in a recent study on the role of GABA in the $P$. syringae pv. tomato-Arabidopsis interaction (Park et al. 2010). The authors have demonstrated several important findings: first, that GABA is a suitable nutrient source for the pathogen in in vitro cultures; second, that higher levels of GABA are induced in the host in response to the infection; third, that Arabidopsis pop 2-1 mutants, accumulating higher levels of GABA, exhibit reduced susceptibility to the pathogen; and, finally and most importantly, deficiency in the GABA catabolic pathway in the pathogen also results in reduced susceptibility in the host. These results give support to the hypothesis that active utilization of a particular amino acid by $P$. syringae is not always just a nutritional preference but, beyond that, it may function as a "virulence strategy" via which the pathogen interferes with an effective defense component of its host.

Conversely, by neglecting a particular amino acid or intermediate metabolite, the pathogen may prevent activation of the associated biosynthetic pathway. This may explain why $P$. $s y$ ringae lacks the glycerate pathway, which is necessary for glyoxylate utilization (Rico and Preston 2008). Because glyoxylate is not used as a $\mathrm{C}$ source, further stimulation of the $\mathrm{H}_{2} \mathrm{O}_{2}$ generating GOX enzyme (Fig. 1) is avoided, leading to attenuation of the HR response in the host.

\section{Targets for future research.}

In this review, we tried to explain how alterations in host GM can lead to either susceptibility or resistance, depending on the lifestyle of the pathogen. We hope that the enduranceor-evasion model may inspire further research in this fascinating but underexplored area.

To further substantiate the concepts of this review, glutamate (and possibly other key metabolites) could be labeled with stable isotopes such as ${ }^{13} \mathrm{C}$ and ${ }^{15} \mathrm{~N}$ to study its metabolic flux in the GM-dependent metabolic pathways depicted in Figure 1 upon pathogen challenge.

The observed alterations in host GM are clearly the result of a dynamic interplay between the host, trying to defend itself, and the pathogen, manipulating the host metabolism for its own benefit. We need a better understanding of the virulence factors of the pathogen such as toxins and effector proteins that modify the host GM. Moreover, the hypothesis that pathogens utilize certain amino acids to interfere with plant defense should be tested via mutants impaired in the uptake or metabolization of these compounds. To fully understand the metabolic events that rule plant-pathogen interactions, metabolic changes need to be studied in both the host and the pathogen, which is clearly exemplified by the GABA work of Park and associates (2010) discussed above. Analytical techniques that can help to achieve this are summarized by Rico and associates (2011) and Allwood and associates (2008). Novel approaches such as "dual metabolomics" described by Allwood and associates (2010) will be very helpful in this respect. In this method, plant cell cultures and pathogens are co-cultured for a certain amount of time and separated by filtration; subsequently, Fourier transform infrared spectroscopy is used to study the intracellular metabolomes of pathogen and plant cells (metabolic fingerprints), and the metabolites are extruded in the supernatants (metabolic footprints).

The role of plant hormones such as abscisic acid in host GM alterations is unclear and needs to be further explored. Finally,

Table 2. Examples of pathogen-secreted toxins that target host central carbon/nitrogen $(\mathrm{C} / \mathrm{N})$ metabolism ${ }^{\mathrm{a}}$

\begin{tabular}{|c|c|c|c|c|}
\hline Toxin & Pathogen & Host & Mode of action on host central $\mathrm{C} / \mathrm{N}$ metabolism & Reference \\
\hline Tabtoxin & Pseudomonas syringae pv. tabaci & Tobacco, pea & $\begin{array}{l}\text { Irreversible inhibition of GS, disruption of } \\
\text { the GS/GOGAT cycle }\end{array}$ & $\begin{array}{l}\text { Thomas et al. 1983; } \\
\text { Turner } 1981\end{array}$ \\
\hline Mangotoxin & P. syringae pv. syringae & Mango & $\begin{array}{l}\text { Inhibition of OAT, downregulation of } \\
\text { Orn biosynthesis }\end{array}$ & Arrebola et al. 2003 \\
\hline Phaseolotoxin & P. syringae pv. phaseolicola & Vetch & $\begin{array}{l}\text { Inhibition of OCT, downregulation of } \\
\text { Arg biosynthesis }\end{array}$ & Patil et al. 1972 \\
\hline Unknown & P. syringae pv. tomato & Tomato & Downregulation of Orn biosynthesis & Arrebola et al. 2003 \\
\hline ACR-toxin & Alternaria citri & Lemon & Induction of $\mathrm{NAD}^{+}$leakage from the TCA cycle & Tsuge et al. 2013 \\
\hline Victorin & Cochliobolus victoriae & Oat & $\begin{array}{l}\text { Inhibition of GDC, accumulation of free ammonium } \\
\text { in the cytosol }\end{array}$ & Navarre and Wolpert 1999 \\
\hline
\end{tabular}

a GS: glutamine synthetase; GOGAT: Gln-oxoglutarate aminotransferase; OAT: ornithine N-acetyl-transferase; Orn: ornithine; OCT: ornithine cabamoyltransferase; Arg: arginine; TCA: tricarboxylic acid; GDC: glycine decarboxylase. 
it will be interesting to see how environmental factors such as light and $\mathrm{N}$ nutrition, which are known to have profound effects on amino acid levels in the plant leaf (Jänkänpää et al. 2012; Urbanczyk-Wochniak and Fernie 2005), interfere with the host GM and disease susceptibility. We believe that a better understanding of the role of plant GM in disease resistance can lead to new insights and strategies to control plant diseases.

\section{ACKNOWLEDGMENTS}

This work was supported by grants from the Fund for Scientific Research Flanders (FWO grants 3G052607 and 3G000210) and by a specialization fellowship of the Flemish Institute for the Stimulation of ScientificTechnological Research in Industry (IWT, Belgium) given to J. Van Bockhaven. H. S. Seifi thanks D. De Vleesschauwer for his encouraging remarks and his suggestion on the title.

\section{LITERATURE CITED}

AbuQamar, S., Chen, X., Dhawan, R., Bluhm, B., Salmeron, J., Lam, S., Dietrich, R. A., and Mengiste, T. 2006. Expression profiling and mutant analysis reveals complex regulatory networks involved in Arabidopsis response to Botrytis infection. Plant J. 48:28-44.

Allwood, J. W., Ellis, E. I., and Goodacre, R. 2008. Metabolomic technologies and their application in the study of plants and plant-host interactions. Physiol. Plant. 132:117-135.

Allwood, J. W., Clarke, A., Goodacre, R., and Mur, L. A. J. 2010. Dual metabolomics: A novel approach to understanding plant-pathogen interactions. Phytochemistry 71:590-597.

Araujo, W. L., Nunes-Nesi, A., Trenkamp, S., Bunik, V. I., and Fernie, A. R. 2008. Inhibition of 2-oxoglutarate dehydrogenase in potato tuber suggests the enzyme is limiting for respiration and confirms its importance in nitrogen assimilation. Plant Physiol. 148:1782-1796.

Arrebola, E., Cazorla, F. M., Duran, V. E., Rivera, E., Olea, F., Codina, J. C., Perez-Garcia, A., and de Vicente, A. 2003. Mangotoxin: A novel antimetabolite toxin produced by Pseudomonas syringae inhibiting ornithine/arginine biosynthesis. Physiol. Mol. Plant Pathol. 63:117127.

Arrebola, E., Cazorla, F. M., Perez-Garcia, A., and de Vicente, A. 2011. Chemical and metabolic aspects of antimetabolite toxins produced by Pseudomonas syringae pathovars. Toxins 3:1089-1110.

Asselbergh, B., Curvers, K., Franca, S. C., Audenaert, K., Vuylsteke, M., Van Breusegem, F., and Höfte, M. 2007. Resistance to Botrytis cinerea in sitiens, an abscisic acid-deficient tomato mutant, involves timely production of hydrogen peroxide and cell wall modifications in the epidermis. Plant Physiol. 144:1863-1877.

Berger, S., Sinha, A. K., and Roitsch, T. 2007. Plant physiology meets phytopathology: Plant primary metabolism and plant-pathogen interactions. J. Exp. Bot. 58:4019-4026.

Bernard, S. M., and Habash, D. Z. 2009. The importance of cytosolic glutamine synthetase in nitrogen assimilation and recycling. New Phytol. 182:608-620.

Block, A., Li, G., Qing Fu, J., and Alfano, J. R. 2008. Phytopathogen type III effector weaponry and their plant targets. Curr. Opin. Plant Biol. 11:396-403.

Bolton, M. D. 2009. Primary metabolism and plant defense-fuel for the fire. Mol. Plant-Microbe Interact. 22:487-497.

Bolton, M. D., and Thomma, B. P. H. J. 2008. The complexity of nitrogen metabolism and nitrogen-regulated gene expression in plant pathogenic fungi. Physiol. Mol. Plant Pathol. 72:104-110.

Bolton, M. D., Kolmer, J. A., Xu, W. W., and Garvin, D. F. 2008. Lr34-mediated leaf rust resistance in wheat: Transcript profiling reveals a high energetic demand supported by transient recruitment of multiple metabolic pathways. Mol. Plant-Microbe Interact. 21:1515-1527.

Bouché, N., Fait, A., Bouchez, D., Moller, S. G., and Fromm, H. 2003. Mitochondrial succinic-semialdehyde dehydrogenase of the gammaaminobutyrate shunt is required to restrict levels of reactive oxygen intermediates in plants. Proc. Natl. Acad. Sci. U.S.A. 100:6843-6848.

Brauc, S., De Vooght, E., Claeys, M., Höfte, M., and Angenon, G. 2011. Influence of over-expression of cytosolic aspartate aminotransferase on amino acid metabolism and defence responses against Botrytis cinerea infection in Arabidopsis thaliana. J. Plant Physiol. 168:1813-1819.

Brauc, S., De Vooght, E., Claeys, M., Geuns, J. M. C., Höfte, M., and Angenon, G. 2012. Overexpression of arginase in Arabidopsis thaliana influences defence responses against Botrytis cinerea. Plant Biol. $14: 39-45$.

Cecchini, N. M., Monteoliva, M. I., and Alvarez, M. E. 2011. Proline de- hydrogenase contributes to pathogen defense in Arabidopsis. Plant Physiol. 155:1947-1959.

Cowley, T., and Walters, D. R. 2002. Polyamine metabolism in an incompatible interaction between barley and the powdery mildew fungus, Blumeria graminis f. sp. hordei. J. Phytopathol. 150:581-586.

Crawford, N. M. 2006. Mechanisms for nitric oxide synthesis in plants. J. Exp. Bot. 57:471-478.

Cren, M., and Hirel, B. 1999. Glutamine synthetase in higher plants: Regulation of gene and protein expression from the organ to the cell. Plant Cell Physiol. 40:1187-1193.

Curvers, K., Seifi, H., Mouille, G., de Rycke, R., Asselbergh, B., Van Hecke, A., Vanderschaeghe, D., Höfte, H., Callewaert, N., Van Breusegem, F., and Höfte, M. 2010. Abscisic acid deficiency causes changes in cuticle permeability and pectin composition that influence tomato resistance to Botrytis cinerea. Plant Physiol. 154:847-860.

Dangl, J. L., and Jones, J. D. G. 2001. Plant pathogens and integrated defence responses to infection. Nature 411:826-833.

De Gara, L., de Pinto, M. C., and Tommasi, F. 2003. The antioxidant systems vis-a-vis reactive oxygen species during plant-pathogen interaction. Plant Physiol. Biochem. 41:863-870.

Dennis, D. T., and Blakeley, S. D. 1995. The regulation of carbon partitioning in plants. Curr. Top. Plant Physiol. 13:258-267.

Duke, D. O., and Dayan, F. E. 2011. Mode of action of microbially produced phytotoxins. Toxins 3:1038-1064.

Dulermo, T., Bligny, R., Gout, E., and Cotton, P. 2009. Amino acid changes during sunflower infection by the necrotrophic fungus $B$. cinerea. Plant Signal. Behav. 4:859-861.

El-Zahaby, H. M., Gullner, G., and Kiraly, Z. 1995. Effects of powdery mildew infection of barley on the ascorbate-glutathione cycle and other antioxidants in different host-pathogen interactions. Phytopathology $85: 1225-1230$

Fabro, G., Kovacs, I., Pavet, V., Szabados, L., and Alvarez, M. E. 2004 Proline accumulation and AtP5CS2 gene activation are induced by plant-pathogen incompatible interactions in Arabidopsis. Mol. PlantMicrobe Interact. 17:343-350.

Fahnenstich, H., Scarpeci, T. E., Valle, E. M., Flugge, U. I., and Maurino, V. G. 2008. Generation of hydrogen peroxide in chloroplasts of Arabidopsis overexpressing glycolate oxidase as an inducible system to study oxidative stress. Plant Physiol. 148:719-729.

Fait, A., Fromm, H., Walter, D., Galili, G., and Fernie, A. R. 2008. Highway or byway: The metabolic role of the GABA shunt in plants. Trends Plant Sci. 13:14-19.

Fodor, J., Gullner, G., Adam, A. L., Barna, B., Komives, T., and Kiraly, Z. 1997. Local and systemic responses of antioxidants to tobacco mosaic virus infection and to salicylic acid in tobacco-Role in systemic acquired resistance. Plant Physiol. 114:1443-1451.

Forde, B. G., and Lea, P. J. 2007. Glutamate in plants: Metabolism, regulation, and signalling. J. Exp. Bot. 58:2339-2358.

Foyer, C. H., and Noctor, G. 2005. Redox homeostasis and antioxidant signaling: A metabolic interface between stress perception and physiological responses. Plant Cell 17:1866-1875.

Galili, G., Tang, G. L., Zhu, X. H., and Gakiere, B. 2001. Lysine catabolism: A stress and development super-regulated metabolic pathway. Curr. Opin. Plant Biol. 4:261-266.

Govrin, E. M., and Levine, A. 2000. The hypersensitive response facilitates plant infection by the necrotrophic pathogen Botrytis cinerea. Curr. Biol. 10:751-757.

Grosskinsky, D. K., Koffler, B. E., Roitsch, T., Maier, R., and Zechmann, B. 2012. Compartment-specific antioxidative defense in Arabidopsis against virulent and avirulent Pseudomonas syringae. Phytopathology 102:662-673.

Hare, P. D., and Cress, W. A. 1997. Metabolic implications of stressinduced proline accumulation in plants. Plant Growth Regul. 21:79-102.

Heil, M., and Bostock, R. M. 2002. Induced systemic resistance (ISR) against pathogens in the context of induced plant defences. Ann. Bot. 89:503-512.

Hoffland, E., Jeger, M. J., and van Beusichem, M. L. 2000. Effect of nitrogen supply rate on disease resistance in tomato depends on the pathogen. Plant Soil 218:239-247.

Horst, R. J., Doehlemann, G., Wahl, R., Hofmann, J., Schmiedl, A., Kahmann, R., Kamper, J., Sonnewald, U., and Voll, L. M. 2010. Ustilago maydis infection strongly alters organic nitrogen allocation in maize and stimulates productivity of systemic source leaves. Plant Physiol. 152:293-308.

Hwang, I. S., An, S. H., and Hwang, B. K. 2011. Pepper asparagine synthetase $1(\mathrm{CaAS} 1)$ is required for plant nitrogen assimilation and defense responses to microbial pathogens. Plant J. 67:749-762.

Jänkänpää, H. J., Mishra, Y., Schröder, W. P., and Jansson, S. 2012. Metabolic profiling reveals metabolic shifts in Arabidopsis plants grown under different light conditions. Plant Cell Environ. 35:1824-1836. 
Kang, S., Kim, H. B., Lee, H., Choi, J. Y., Heu, S., Oh, C. J., Kwon, S. I., and An, C. S. 2006. Overexpression in Arabidopsis of a plasma membrane-targeting glutamate receptor from small radish increases glutamate-mediated $\mathrm{Ca}^{2+}$ influx and delays fungal infection. Mol. Cells 21:418-427.

Kenigsbuch, D., and Cohen, Y. 1992. Inheritance of resistance to downy mildew in Cucumis melo Pi-124112 and commonality of resistance genes with Pi-124111F. Plant Dis. 76:615-617.

Kim, H. B., Lee, S. H., and An, C. S. 1999. Isolation and characterization of a cDNA clone encoding asparagine synthetase from root nodules of Elaeagnus umbellata. Plant Sci. 149:85-94.

Kinnersley, A. M., and Turano, F. J. 2000. Gamma aminobutyric acid (GABA) and plant responses to stress. Crit. Rev. Plant Sci. 19:479-509.

Kornberg, H. L. 1965. Anaplerotic sequences in microbial metabolism. Angew. Chem. Int. 4:558-565.

Kuznetsov, V. V., Radyukina, N. L., and Shevyakova, N. I. 2006. Polyamines and stress: Biological role, metabolism, and regulation. Russ. J. Plant Physiol. 53:583-604.

Kuzniak, E., and Sklodowska, M. 1999. The effect of Botrytis cinerea infection on ascorbate-glutathione cycle in tomato leaves. Plant Sci. 148:69-76.

Lam, H. M., Coschigano, K. T., Oliveira, I. C., MeloOliveira, R., and Coruzzi, G. M. 1996. The molecular genetics of nitrogen assimilation into amino acids in higher plants. Annu. Rev. Plant Physiol. Plant Mol. Biol. 47:569-593.

Lea, P. J, and Azevedo, R. A. 2007. Nitrogen use efficiency. 2. Amino acid metabolism. Ann. Appl. Biol. 151:269-275.

Lecompte, F., Abro, M. A., and Nicot, P. C. 2010. Contrasted responses of Botrytis cinerea isolates developing on tomato plants grown under different nitrogen nutrition regimes. Plant Pathol. 59:891-899.

Liu, G. S., Ji, Y. Y., Bhuiyan, N. H., Pilot, G., Selvaraj, G., Zou, J. T., and Wei, Y. D. 2010. Amino acid homeostasis modulates salicylic acid-associated redox status and defense responses in Arabidopsis. Plant Cell 22:3845-3863.

Ludewig, F., Huser, A., Fromm, H., Beauclair, L., and Bouché, N. 2008. Mutants of GABA transaminase (POP2) suppress the severe phenotype of succinic semialdehyde dehydrogenase (ssadh) mutants in Arabidopsis. Plos One 3:10.

Masclaux-Daubresse, C., Valadier, M. H., Carrayol, E., Reisdorf-Cren, M., and Hirel, B. 2002. Diurnal changes in the expression of glutamate dehydrogenase and nitrate reductase are involved in the $\mathrm{C} / \mathrm{N}$ balance of tobacco source leaves. Plant Cell Environ. 11:1451-1462.

Mhamdi, A., Mauve, C., Gouia, H., Saindrenan, P., Hodges, M., and Noctor, G. 2010. Cytosolic NADP-dependent isocitrate dehydrogenase contributes to redox homeostasis and the regulation of pathogen responses in Arabidopsis leaves. Plant Cell Environ. 33:1112-1123.

Michaeli, S., Fait, A., Lagor, K., Nunes-Nesi, A., Grillich, N., Yellin, A., Bar, D., Khan, M., Fernie, A. R., Turano, F. J., and Fromm, H. 2011. A mitochondrial GABA permease connects the GABA shunt and the TCA cycle, and is essential for normal carbon metabolism. Plant J. 67:485498

Miller, G., Honig, A., Stein, H., Suzuki, N., Mittler, R., and Zilberstein, A. 2009. Unraveling delta(1)-pyrroline-5-carboxylate-proline cycle in plants by uncoupled expression of proline oxidation enzymes. J. Biol. Chem. 284:26482-26492.

Moreau, M., Lindermayr, C., Durner, J., and Klessig, D. F. 2010. NO synthesis and signaling in plants-where do we stand? Physiol. Plant. 138:372-383.

Mur, L. A. J., Carver, T. L. W., and Prats, E. 2006. NO way to live: The various roles of nitric oxide in plant-pathogen interactions. J. Exp. Bot. 57:489-505

Natarajan, S. K., and Becker, D. F. 2012. Role of apoptosis-inducing factor, proline dehydrogenase, and NADPH oxidase in apoptosis and oxidative stress. Cell Health Cytoskelet. 2012:11-27.

Navarre, D. A., and Wolpert, T. J. 1999. Victorin induction of an apoptotic/senescence-like response in oats. Plant Cell 11:237-249.

Noctor, G., Mhamdi, A., Chaouch, S., Han, Y., Neukermans, J., MarquezGarcia, B., Queval, G., and Foyer, C. H. 2012. Glutathione in plants: An integrated overview. Plant Cell Environ. 35:454-484.

Olea, F., Perez-Garcia, A., Canton, F. R., Rivera, M. E., Canas, R., Avila, C., Cazorla, F. M., Canovas, F. M., and de Vicente, A. 2004. Up-regulation and localization of asparagine synthetase in tomato leaves infected by the bacterial pathogen Pseudomonas syringae. Plant Cell Physiol. 45:770-780.

Pageau, K., Reisdorf-Cren, M., Morot-Gaudry, J. F., and MasclauxDaubresse, C. 2006. The two senescence-related markers, GS1 (cytosolic glutamine synthetase) and GDH (glutamate dehydrogenase), involved in nitrogen mobilization, are differentially regulated during pathogen attack and by stress hormones and reactive oxygen species in Nicotiana tabacum L. leaves. J. Exp. Bot. 57:547-557.
Park, D. H., Mirabella, R., Bronstein, P. A., Preston, G. M., Haring, M. A., Lim, C. K., Collmer, A., and Schuurink, R. C. 2010. Mutations in gamma-aminobutyric acid (GABA) transaminase genes in plants or Pseudomonas syringae reduce bacterial virulence. Plant J. 64:318-330.

Patil, S. S., Tam, L. Q., and Sakai, W. S. 1972. Mode of action of the toxin from Pseudomonas phaseolicola .I. Toxin specificity, chlorosis, and ornithine accumulation. Plant Physiol. 49:803-807.

Perez-Garcia, A., Canovas, F. M., Gallardo, F., Hirel, B., and Devicente, A. 1995. Differential expression of glutamine synthetase isoforms in tomato detached leaflets infected with Pseudomonas syringae pv. tomato. Mol. Plant-Microbe Interact. 8:96-103.

Perez-Garcia, A., de Vicente, A., Canton, F. R., Cazorla, F. M., Codina, J. C., Garcia-Gutierrez, A., and Canovas, F. M. 1998a. Light-dependent changes of tomato glutamine synthetase in response to Pseudomonas syringae infection or phosphinothricin treatment. Physiol. Plant. $102: 377-384$

Perez-Garcia, A., Pereira, S., Pissarra, J., Gutierrez, A. G., Cazorla, F. M., Salema, R., de Vicente, A., and Canovas, F. M. 1998b. Cytosolic localization in tomato mesophyll cells of a novel glutamine synthetase induced in response to bacterial infection or phosphinothricin treatment. Planta 206:426-434.

Perez-Garcia, A., Snoeijers, S. S., Joosten, M. H. A. J., Goosen, T., and De Wit, P. J. G. M. 2001. Expression of the avirulence gene Avr9 of the fungal tomato pathogen Cladosporium fulvum is regulated by the global nitrogen response factor NRF1. Mol. Plant-Microbe Interact. 14:316325.

Phang, J. M., Donald, S. P., Pandhare, J., and Liu, Y. M. 2008. The metabolism of proline, a stress substrate, modulates carcinogenic pathways. Amino Acids 35:681-690.

Pieterse, C. M. J., Verbakel, H. M., Spaans, J. H., Davidse, L. C., and Govers, F. 1993. Increased expression of the calmodulin gene of the late blight fungus Phytophthora infestans during pathogenesis on potato. Mol. Plant-Microbe Interact. 6:164-172.

Rico, A., and Preston, G. M. 2008. Pseudomonas syringae pv. tomato DC3000 uses constitutive and apoplast-induced nutrient assimilation pathways to catabolize nutrients that are abundant in the tomato apoplast. Mol. Plant-Microbe Interact. 21:269-282.

Rico, A., McCraw, S. L., and Preston, G. M. 2011. The metabolic interface between Pseudomonas syringae and plant cells. Curr. Opin. Microbiol. 14:31-38.

Rojas, C. M., Senthil-Kumar, M., Wang, K., Ryu, C. M., Kaundal, A., and Mysore, K. S. 2012. Glycolate oxidase modulates reactive oxygen species-mediated signal transduction during nonhost resistance in Nicotiana benthamiana and Arabidopsis. Plant Cell 24:336-352.

Senthil-Kumar, M., and Mysore, K. S. 2012. Ornithine-delta-aminotransferase and proline dehydrogenase genes play a role in non-host disease resistance by regulating pyrroline-5-carboxylate metabolism-induced hypersensitive response. Plant Cell Environ. 35:1329-1343.

Servet, C., Ghelis, T., Richard, L., Zilberstein, A., and Savoure, A. 2012. Proline dehydrogenase: A key enzyme in controlling cellular homeostasis. Front. Biosci. 17:607-620.

Shelp, B. J., Mullen, R. T., and Waller, J. C. 2012. Compartmentation of GABA metabolism raises intriguing questions. Trends Plant Sci. 17:5759.

Shibata, Y., Kawakita, K., and Takemoto, D. 2010. Age-related resistance of Nicotiana benthamiana against hemibiotrophic pathogen Phytophthora infestans requires both ethylene- and salicylic acid-mediated signaling pathways. Mol. Plant-Microbe Interact. 23:1130-1142.

Solomon, P. S., and Oliver, R. P. 2001. The nitrogen content of the tomato leaf apoplast increases during infection by Cladosporium fulvum. Planta 213:241-249

Solomon, P. S., and Oliver, R. P. 2002. Evidence that gamma-aminobutyric acid is a major nitrogen source during Cladosporium fulvum infection of tomato. Planta 214:414-420.

Solomon, P. S., Tan, K. C., and Oliver, R. P. 2003. The nutrient supply of pathogenic fungi; a fertile field for study. Mol. Plant Pathol. 4:203-210.

Studart-Guimaraes, C., Fait, A., Nunes-Nesi, A., Carrari, F., Usadel, B., and Fernie, A. R. 2007. Reduced expression of succinyl-coenzyme A ligase can be compensated for by up-regulation of the gamma-aminobutyrate shunt in illuminated tomato leaves. Plant Physiol. 145:626-639.

Swartzberg, D., Kirshner, B., Rav-David, D., Elad, Y., and Granot, D. 2008. Botrytis cinerea induces senescence and is inhibited by autoregulated expression of the IPT gene. Eur. J. Plant Pathol. 120:289-297.

Szabados, L., and Savoure, A. 2010. Proline: A multifunctional amino acid. Trends Plant Sci. 15:89-97.

Taler, D., Galperin, M., Benjamin, I., Cohen, Y., and Kenigsbuch, D. 2004. Plant eR genes that encode photorespiratory enzymes confer resistance against disease. Plant Cell 16:172-184.

Tavernier, V., Cadiou, S., Pageau, K., Lauge, R., Reisdorf-Cren, M., Langin, T., and Masclaux-Daubresse, C. 2007. The plant nitrogen mobi- 
lization promoted by Colletotrichum lindemuthianum in Phaseolus leaves depends on fungus pathogenicity. J. Exp. Bot. 58:3351-3360.

Thomas, M. D., Langstonunkefer, P. J., Uchytil, T. F., and Durbin, R. D. 1983. Inhibition of glutamine synthetase from pea by tabtoxinine beta lactam. Plant Physiol. 71:912-915.

Tourte, C., and Manceau, C. 1995. A strain of Pseudomonas syringae which does not belong to pathovar phaseolicola produces phaseolotoxin. Eur. J. Plant Pathol. 101:483-490.

Tsuge, T., Harimoto, Y., Akimitsu, K., Ohtani, K., Kodama, M., Akagi, Y., Egusa, M., Yamamoto, M., and Otani, H. 2013. Host-selective toxins produced by the plant pathogenic fungus Alternaria alternata. FEMS (Fed. Eur. Microbiol. Soc.) Microbiol. Rev. 37:44-66.

Turner, J. G. 1981. Tabtoxin, produced by Pseudomonas tabaci, decreases Nicotiana tabacum glutamine synthetase in vivo and causes accumulation of ammonia. Physiol. Plant Pathol. 19:57-67.

Urbanczyk-Wochniak, E., and Fernie, A. R. 2005. Metabolic profiling reveals altered nitrogen nutrient regimes have diverse effects on the metabolism of hydroponically grown tomato (Solanum lycopersicum) plants. J. Exp. Bot. 56:309-321.

Van Baarlen, P., Staats, M., and Van Kan, J. A. L. 2004. Induction of programmed cell death in lily by the fungal pathogen Botrytis elliptica. Mol. Plant Pathol. 5:559-574.

van den Ackerveken, G. F. J. M., Dunn, R. M., Cozijnsen, A. J., Vossen, J. P. M. J., Vandenbroek, H. W. J., and Dewit, P. J. G. M. 1994. Nitrogen limitation induces expression of the avirulence gene Avr9 in the tomato pathogen Cladosporium fulvum. Mol. Gen. Genet. 243:277-285.

van Doorn, W. G., Beers, E. P., Dangl, J. L., Franklin-Tong, V. E., Gallois, P., Hara-Nishimura, I., Jones, A. M., Kawai-Yamada, M., Lam, E., Mundy, J., Mur, L. A. J., Petersen, M., Smertenko, A., Taliansky, M.,
Van Breusegem, F., Wolpert, T., Woltering, E., Zhivotovsky, B., and Bozhkov, P. V. 2011. Morphological classification of plant cell deaths. Cell Death Differ. 18:1241-1246.

Verbruggen, N., and Hermans, C. 2008. Proline accumulation in plants: A review. Amino Acids 35:753-759.

Vongonner, M., and Schlosser, E. 1993. Oxidative stress in interactions between Avena sativa and Drechslera spp. Physiol. Mol. Plant Pathol. 42:221-234.

Walters, D. R. 2003. Polyamines and plant disease. Phytochemistry 64:97107.

Walters, D. R., and Bingham, I. J. 2007. Influence of nutrition on disease development caused by fungal pathogens: Implications for plant disease control. Ann. Appl. Biol. 151:307-324.

Ward, J. L., Forcat, S., Beckmann, M., Bennett, M., Miller, S. J., Baker, J. M., Hawkins, N. D., Vermeer, C. P., Lu, C. A., Lin, W. C., Truman, W. M., Beale, M. H., Draper, J., Mansfield, J. W., and Grant, M. 2010. The metabolic transition during disease following infection of Arabidopsis thaliana by Pseudomonas syringae pv. tomato. Plant J. 63:443-457.

Wu, C. X., Zhou, S. Y., Zhang, Q., Zhao, W. S., and Peng, Y. L. 2006. Molecular cloning and differential expression of a gamma-aminobutyrate transaminase gene, OsGABA-T, in rice (Oryza sativa) leaves infected with blast fungus. J. Plant Res. 119:663-669.

Zheng, Y., Sheng, J. P., Zhao, R. R., Zhang, J., Lv, S. N., Liu, L. Y., and Shen, L. 2011. Preharvest 1-arginine treatment induced postharvest disease resistance to Botrytis cinerea in tomato fruits. J. Agric. Food Chem. 59:6543-6549.

Zurbruggen, M. D., Carrillo, N., and Hajirezaei, M. R. 2010. ROS signaling in the hypersensitive response. When, where and what for? Plant Signal. Behav. 5:393-396. 